\title{
Microwave Assisted Biodiesel Production From Lagenaria Vulgaris Seed Oil Using Amberlyst 15 Ion Exchange Resin and Eggshell as Catalysts
}

\author{
${ }^{* 1}$ A.Umar, ${ }^{2}$ A.Uba, ${ }^{2 M}$.L. Mohammed, ${ }^{2 M}$.N. Almustapha, ${ }^{2}$ C. Muhammad and 2 J. Sani \\ 'Department of Science Technology, Waziri Umaru Federal Polytechnic, Birnin-Kebbi \\ 2Department of Pure and Applied Chemistry, Usmanu Danfodiyo University, Sokoto \\ [*Corresponding Author: E-mail: abukalgo99@gmail.com]
}

\section{ABSTRACT}

The study involves the extraction of oil from the seeds of lagenaria vulgaris (Calabash) using soxhlet apparatus. The physicochemical properties of the calabash seeds oil analyzed were; crude oil yield (37.8\%), density of oil $\left(0.925 \mathrm{~g} / \mathrm{cm}^{3}\right)$, acid value of oil $(5.6 \mathrm{mgKOH} / \mathrm{g})$ and saponification value $(190.1 \mathrm{mgKOH} / \mathrm{g})$.Catalytic transesterification was carried out using the oil produced in a microwave to yield biodiesel. A comparative analysis of the biodiesel produced from the extracted oil using two different catalysts; Amberlyst 15 ion exchange resin and calcium oxide (waste eggshell) was carried out. The biodiesel production was conducted under different catalyst concentrations, different temperature range and different time (minutes). The best yield of $95.07 \%$ was achieved with treated waste eggshell at $60{ }^{\circ} \mathrm{C}, 5 \%$ catalyst to oil ratio and $40 \%$ methanol to oil volume ratio after 40 minutes. Biodiesel characterization showed; specific gravity $\left(0.890 \mathrm{~g} / \mathrm{cm}^{3}\right)$, acid value $(0.7 \mathrm{mgKOH} / \mathrm{g})$, API gravity $\left(27.5 \mathrm{~g} / \mathrm{cm}^{3}\right)$, kinematic viscosity $\left(5.6 \mathrm{~mm}^{2} / \mathrm{s}\right)$, cloud point $\left(3.5^{\circ} \mathrm{C}\right)$, pour point $\left(-3^{\circ} \mathrm{C}\right)$, copper strip corrosion test $(1 \mathrm{~b})$, flash point $\left(138^{\circ} \mathrm{C}\right)$, cetane/diesel index (35.1). The result shows that the biodiesel quality parameters were within the acceptable limits set by ASTM, although blends and additives maybe needed to improve performance.

Keywords: Biodiesel, Transesterification, Amberlyst 15, Eggshell.

\section{INTRODUCTION}

Biodiesel is an alternative fuel for diesel engines that is receiving great attention worldwide. It attracts the most attention because it is renewable, it can be used either pure or in blends with diesel conventional fuel in unmodified diesel engines and it reduces exhaust pollutants. It is also attractive as it can be produced easily from common feedstock (Van-Gerpen et al., 2004).

Rudolph Diesel was the first to use a vegetable oil (peanut oil) in a diesel engine in 1911 (Akoh et al., 2007; Antczak et al., 2009). The use of biofuels in place of conventional fuels is thought toslow the progression of global warming by reducing sulfur, carbon oxides and hydrocarbon emission (Fjerback et al., 2009). To achieve better economic benefits and more power output, biodiesel is often blended with diesel fuel since higher biodiesel to diesel fuel ratio lowers carbon dioxide emission (Vasudevan and Briggs, 2008).
Biodiesel production is a new field of research discovered in recent past and more research work is needed to be conducted in that aspect. The dominance of liquid catalysis in the production of biodiesel comes with peculiar challenges such as availability of pure grade catalyst, cost of purchase and separation of the catalyst from the produced biodiesel. However, heterogeneous catalysts can be used due to their availability and re-usability over a period of time. Solid heterogeneous catalysts have been used in the transesterification process due to their numerous advantages over homogenous catalysts (Marwaha et al., 2018). For instance Colombo et al. (2017) reported biodiesel production using calcium oxide $(\mathrm{CaO})$ as heterogeneous catalyst and achieve nearly 100\% conversion. Hence, waste egg shell, which is known to be a cheap source of $\mathrm{CaO}$ could be applied as a catalyst in biodiesel production. Additionally, the use of microwave technology will 
lower the energy (power) consumption, and heating cost.

This study investigates biodiesel production from Lagenaria vulgaris (calabash) seeds oil using two different catalysts by studying the effects of various parameters such as reaction temperature, reaction time and catalyst concentration in a microwave.

\section{MATERIALS AND METHODS}

\section{Sample Collection and Preparation}

The Lagenaria vulgaris (calabash) seeds were collected from Gummi town in Gummi Local Government Area of Zamfara state, Nigeria. The seeds were de-husked and dried under the sun for two days, so as to reduce their moisture content. Fifty gram $(50 \mathrm{~g})$ of the powdered seed was transferred into a porous thimble of a Soxhlet extractor and the oil was extracted using $\mathrm{n}$ hexane at $69^{\circ} \mathrm{C}$ for $3 \mathrm{~h}$. The oil was separated from the solvent using a rotary evaporator.

\section{Catalyst (egg shell) Preparation}

Eggshell was collected from local tea shops. The eggshell was rinsed several times with deionized water to remove impurities, and it was dried at $100^{\circ} \mathrm{C}$ for $24 \mathrm{~h}$ in a dry oven. Calcination was performed in a muffle furnace at a temperature of $900^{\circ} \mathrm{C}-950^{\circ} \mathrm{C}$ for $4 \mathrm{~h}$ after crushing the dried eggshell (Ziku et al., 2008). Eggshell (calcined) and Amberlyst 15 ion exchange resin (Sigma Aldrich, USA) were used as catalysts in this experiment.

\section{Acid Pre-Treatment of Calabash Seed Oil}

Approximately $100 \mathrm{~cm}^{3}$ of calabash seed oil was introduced in a reactor flask and heated in a microwave to $100^{\circ} \mathrm{C}$ while stirring. This was repeated severally while keeping the oil volume constant and changing the acid to oil ratio i.e. using $0.50 \%, 0.75 \%, 1.0 \%, 1.25 \% \mathrm{v} / \mathrm{v}$ of sulphuric acid-to-oil volume. Fifty $\left(50 \mathrm{~cm}^{3}\right)$ of methanol was mixed with concentrated sulphuric acid in each of the experiment to obtain the optimum combination where the FFA value is lowest. Afterwards, $1 \%$ sulphuric acid concentration was taken for this analysis since it gave the lowest value of free fatty acid $(0.56 \%)$ from preliminary analysis conducted. The acid was mixed with the oil and stirred for 5 min before adding methanol $\left(50 \mathrm{~cm}^{3}\right)$. The reaction time was kept at $1 \mathrm{~h}$ in all the experiments. The stirrer was stopped when the reaction time was completed and the esterified oil transferred into a separating funnel, which was allowed to stand for $1 \mathrm{~h}$. The methanol-water layer was formed at the top which was subsequently removed by evaporation before analyzing the FFA value. The optimum combination of methanol and acid that produced the lowest FFA value in the oil was obtained. This was then used in transesterification process to produce the methyl ester (Anya et al., 2012).

\section{Physicochemical Analysis of Oil and THE Biodiesel Produced \\ Determination of Calabash Seeds Oil Yield (\%) was obtained using the formula:}

Oil yield $(\%)=\frac{\text { weight of oil extracted }}{\text { weight of powdered seeds used }} \times 100$

Determination of saponification value was conducted as described by Verma, (2001). Acid value test was conducted according to (AOAC, 1990). American Standard for Testing Materials (ASTM) method ASTM D 1298 (1999) was used for density measurement. ASTM D 98 method was used for flash point analysis (Van-Gerpenet al., 2004). ASTM D 611 method was applied for Aniline point determination and diesel index determination was conducted as described by Coker (2010). Cloud point and pour point analyses were conducted using ASTM D 2500 and ASTM D 97 methods respectively (VanGerpenet al., 2004). Digital Viscometer (NDJ-8S) was used for kinematic viscosity determination. Method number ASTM 130 was used for Copper strip corrosion test. Method number ASTM D 2709 was applied for water and sediment analysis as described by Van-Gerpenet al. (2004). 


\section{Umar et al: Microwave Assisted Biodiesel Production From Lagenaria Vulgaris Seed Oil Using......}

\section{GC-MS Analysis}

GC-MS analysis was carried out on the sample using Agilent Technologies 680N GC system and Agilent Technologies 5973 Network Mass selective detector. The carrier gas used was Helium at a flow rate of $1.2 \mu \mathrm{L} / \mathrm{min}$. The injection volume was $1 \mu \mathrm{L}$. The inlet temperature was maintained at $230^{\circ} \mathrm{C}$. The oven temperature was programmed initially at $50^{\circ} \mathrm{C}$ for $5 \mathrm{~min}$, then programmed to increase to $300^{\circ} \mathrm{C}$ at a rate of $10^{\circ} \mathrm{C}$ ending with $25 \mathrm{~min}$. Total run time was $45 \mathrm{~min}$. The MS transfer line was maintained at a temperature of $250^{\circ} \mathrm{C}$. The source temperature was maintained at $230^{\circ} \mathrm{C}$ and the MS quad at $150^{\circ} \mathrm{C}$. The ionization mode used was electron ionization mode at $70 \mathrm{ev}$. Total ion count (TIC) was used to evaluate for compound identification and quantitation. The spectrum of the separated compound was compared with the database of the spectrum of known compound saved in the NIST02 Reference spectra library. Data analysis and peak area measurement was carried out using Agilent chemstation software.

The total yield of biodiesel was obtained (Elkady et al., 2015; Galvez and Berge, 2013) using the formula:

$$
\text { Biodiesel yield (\%) }=\frac{\text { volume of biodiesel produced }}{\text { volume of oil used }} \times \text { FAMEs (\%) from GC }- \text { MS analysis }
$$

\section{Microwave Assisted Biodiesel Production}

Methanol to oil $(30 \mathrm{~g})$ ratio of 2:5 was used in the transesterification process. The reactants were accurately weighed and placed in the reactor vessel. Catalyst ratio of $2 \%, 2.5 \%$, and $5 \%$ to oil $(30 \mathrm{~g})$ were used. The mixture was stirred for 5 min and transferred into the modified microwave oven. The microwave (Swan Retro Digital Microwave - 20l - 800w) was modified by inserting a thermostat to monitor the internal temperature (reaction temperature), and it is kept at the desired range $\left( \pm 3^{\circ} \mathrm{C}\right)$ by switching the instrument off/on. The reactions were carried out at different temperatures $\left(60 \pm 3^{\circ} \mathrm{C}, 55 \pm 3^{\circ} \mathrm{C}\right.$ and $50 \pm 3^{\circ} \mathrm{C}$ ) and at different times (20 min, 30 min and $40 \mathrm{~min}$ ) to study the effects of reaction variables on the yield of biodiesel). The product mixture was transferred to a coned shaped filter paper supported in a $60^{\circ}$ angle funnel at the end of each reaction to separate the solid catalyst from the liquid mixture. The upper layer of biodiesel was collected from the separation funnel using a beaker and weighed (Margarita and Giselo 2011; Kaplan and Bayko, 2014). The analyses were conducted in triplicates using each of Amberlyst -15 ion exchange resin and Eggshell catalysts, and the best yield was selected for GCMS analysis.

\section{Statistical Analysis}

The mean and standard deviation of the yields of biodiesel obtained for the triplicate analyses at different reaction conditions were calculated and graphs were generated in the form of scatterplots, and linear regression was conducted with the aid of Minitab computer application software.

\section{RESULT AND DISCUSSION}

The results of Physico-chemical analysis of the oil are presented in Table 1.

Table 1: Physicochemical Properties of Calabash Seed Oil

\begin{tabular}{ll}
\hline Parameter & Value \\
\hline Calabash seed Oil yield \% & 37.8 \\
Acid value $(\mathrm{mgKOH} / \mathrm{g})$ & 5.6 \\
Free fatty acid $(\mathrm{mgKOH} / \mathrm{g})$ & 2.8 \\
Saponification value & 190.1 \\
(mgKOH/g) & 0.925 \\
Specific gravity & \\
\hline
\end{tabular}

In assessing the economic viability of any biodiesel feedstock, one of the basic factors to be considered is the amount of oil yield realized after oil extraction. It can be seen in Table 1 that the 
crude oil yield is $37.8 \%$. The yield when compared with some of the available literature on the plant is higher than $36.7 \%$ reported by Sokoto et al. (2013). It is lower than $39.3 \%$ obtained by Ibrahim et al., 2016. The differences in the oil yield might be due to the methods of extraction employed.

The free fatty acid is a major and vital parameter to be considered in any transesterification process (biodiesel production). It affects the yield of biodiesel production in base catalyzed transesterification. The free fatty acid in the oil sample was found to be $2.8 \mathrm{mgKOH} / \mathrm{g}$, which also corresponds to an acid value of $5.6 \mathrm{mgKOH} / \mathrm{g}$. The acid value is lower than $5.92 \mathrm{mgKOH} / \mathrm{g}$ determined by Olaefe et al. (2012). The free fatty acid of 2.8 is also lower than that of Sokoto et al. (2013) which was 3.24.

The saponification value of calabash seed oil was determined to be $190.1 \mathrm{mgKOH} / \mathrm{g}$, which is higher than $112.22 \mathrm{mgKOH} / \mathrm{g}$ reported for the same oil by Sokoto et al., (2013). Furthermore, it was lower than $229.6 \mathrm{mgKOH} / \mathrm{g}$ reported by Danjuma and Dandago (2009). The saponification value obtained indicates the presence of moderate percentage of Fatty acids which might lead to soap formation; hence the saponification of product will be exceedingly difficult.

The density or specific gravity of oils varies (depending on the type of oil) with temperature. The range is from 0.91 to $0.93 \mathrm{~g} / \mathrm{cm}^{3}$ between the temperature of $15^{\circ} \mathrm{C}$ and $25^{\circ} \mathrm{c}$, compared to water, whose density is $1.00 \mathrm{~g} / \mathrm{ml}$ (Dorfman, 2000). The specific gravity of calabash seeds oil is 0.925 which is within the oil density limit.

Comparison of Catalytic Performances of Amberlyst 15 lon Exchange Resin and Eggshell in Biodiesel Production

The catalytic efficiency of Amberlyst 15 ion exchange resin and eggshell in biodiesel production was compared by studying the effects of different parameters including catalyst concentration, reaction time and reaction temperature.

\section{Effect of Catalyst Concentration}

The catalyst amount affects the conversion of calabash seed oil to its ester, at least for the molar ratio of alcohol used in this study. Three different catalyst amounts of $2 \%, 2.5 \%$ and $5 \%$ were selected; while the fourth ratio of $10 \%$ was discarded due to formation of gelatinous mixture of catalyst, oil and soap in alkaline transesterification. To make the selection even, the above catalyst concentration ratio to oil were used. Other parameters such as methanol/oil ratio of $40 \% \mathrm{v} / \mathrm{w}$ and $60^{\circ} \mathrm{C}$ were kept constant. From Figure 1 the highest biodiesel conversion yield of $93.2 \%$ and $94.8 \%$ were obtained by using Amberlyst 15 ion exchange resin and Eggshell catalysts at $5 \%$ catalyst concentration respectively. At $2.5 \%$ catalyst concentration, eggshell performs better with $91.6 \%$ while Amberlyst 15 recorded $91.3 \%$ yields. Furthermore, eggshell gave better yield at $2 \%$ with $70.7 \%$ against Amberlyst 15 with $66 \%$.

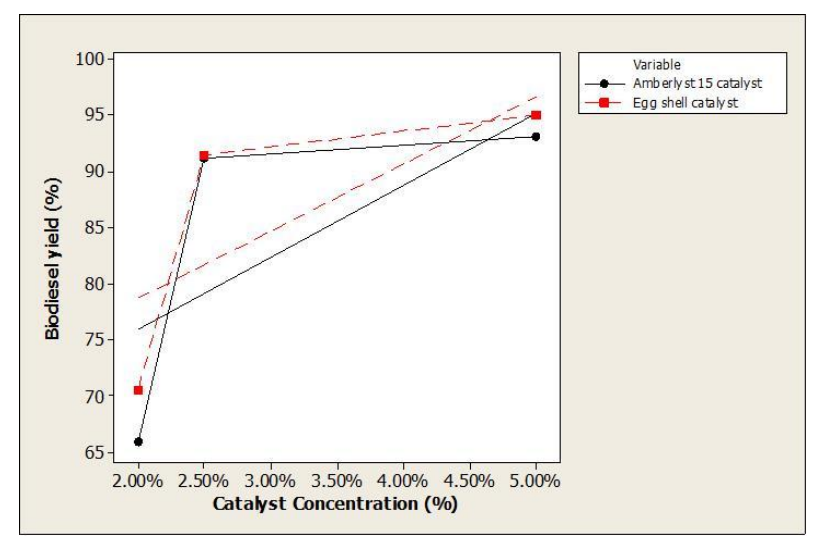

Figure 1: Scatterplot of biodiesel yield versus catalyst concentration of $2 \%, 2.5 \%$ and $5 \%$

\section{Effect of Reaction Time}

The influence of reaction time on the conversion of triglyceride was studied in the range of $20 \mathrm{~min}$, $30 \mathrm{~min}$ and $40 \mathrm{~min}$ and the result were shown in Figure 2. From the result, it can be seen that increase in the reaction time from $20 \mathrm{~min}$ to 30 


\section{Umar et al: Microwave Assisted Biodiesel Production From Lagenaria Vulgaris Seed Oil Using......}

min considerably improved the conversion of triglyceride when Amberlyst 15 was used as catalyst. Further increase in time from 30 min to 40 min increases the yield to the maximum of $93.2 \%$. However, when eggshell was used as catalyst, increase in reaction time from 20 min to 30 min improves the conversion of the oil to biodiesel from $65.3 \%$ to $79.9 \%$, and the subsequent increase of time to 40 min gave corresponding increase in the yield to $94.80 \%$. The best yield of $93.2 \%$ (Amberlyst 15 catalyst) and $94.8 \%$ (Eggshell catalyst) were recorded (Figure 2). In relation to time increment, eggshell catalyst performed better than Amberlyst 15 ion exchange resin. In this study, other parameters were kept constant, such as methanol ration to oil of $40 \% \mathrm{wt}$, catalyst concentration of $5 \%$ to oil and temperature of $60^{\circ} \mathrm{C}$.

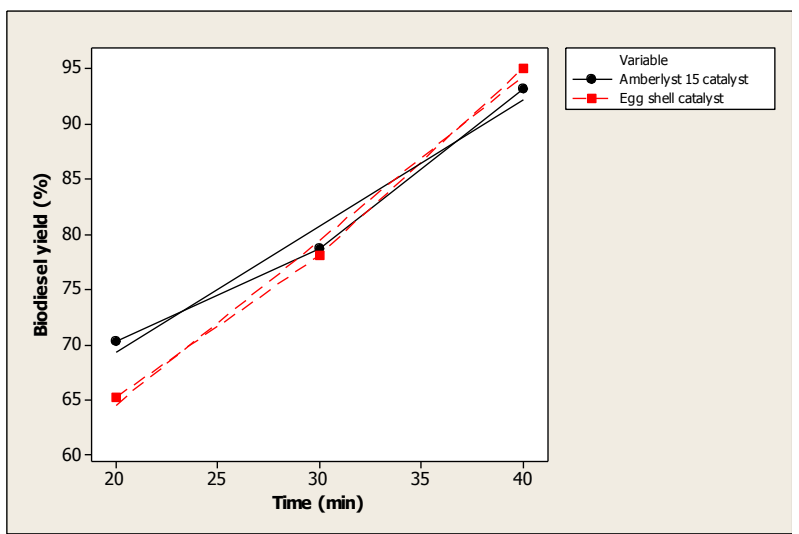

Figure 2: Scatterplot of biodiesel yield versus time (30 min, $30 \mathrm{~min}$ and $40 \mathrm{~min}$ )

\section{Effect of Reaction Temperature}

Reaction temperature is one of the most influencing parameters on the rate of reaction. The effect of temperature on the conversion of triglyceride in biodiesel production was studied. Amberlyst 15 ion exchange resin and Eggshell catalyst were examined at different temperature from $50^{\circ} \mathrm{C}, 55^{\circ} \mathrm{C}$ and $60^{\circ} \mathrm{C}$ with catalyst loading of $5 \% \mathrm{w} / \mathrm{w}$ and methanol/oil ratio of $40 \% \mathrm{w} / \mathrm{w}$ and reaction time of $40 \mathrm{~min}$.

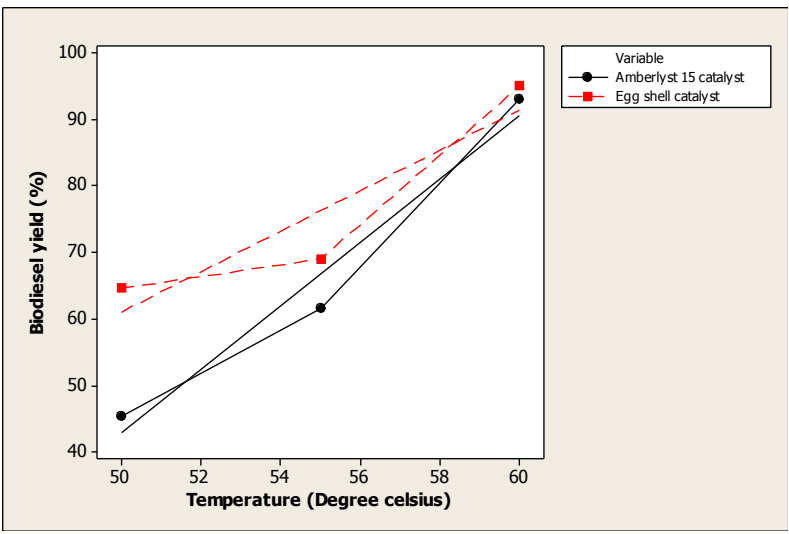

Figure 3: Scatterplot of biodiesel yield versus change in temperature with linear regression

As shown in Figure 3, there was corresponding increase in biodiesel yield with increase in temperature i.e. $43.6 \%, 60.8 \%$ and $93.2 \%$ were obtained at $50^{\circ} \mathrm{C} 55^{\circ} \mathrm{C}$ and $60^{\circ} \mathrm{C}$ respectively, when Amberlyst 15 catalyst was used for biodiesel production. Similarly, when eggshell catalyst was used, there was increase in yield of biodiesel oil produced. For instance, at $50^{\circ} \mathrm{C}$ the yield of $65.2 \%$ was obtained, while at $55^{\circ} \mathrm{C}$ and $60^{\circ} \mathrm{C}$, the yield were $70.1 \%$ and $94.80 \%$ respectively (Figure 3). Further increment in temperature above the boiling point of methanol $\left(65^{\circ} \mathrm{C}\right)$ resulted in a sharp drop in the yield of biodiesel production perhaps due to decomposition of the substrate. Eggshell catalyst performs better than Amberlyst 15 ion exchange resin in regards to effect of reaction temperature.

\section{Fuel Properties of Biodiesel Obtained using Eggshell as Catalyst}

It can be seen from the results of optimisation of reaction conditions for biodiesel production using Amberlyst 15 and Eggshell as catalysts (Figure 1, 2 and 3), that the best yield of biodiesel was obtained when eggshell was used as catalyst. Therefore, the fuel properties of the biodiesel obtained using the catalyst were analysed and the results are presented in Table 2. 
Table 2: Fuel Properties of eggshell catalysed Biodiesel Production from $L$. vulgaris Seeds Oil

\begin{tabular}{lll}
\hline Fuel property & $\begin{array}{l}\text { Biodiesel } \\
\text { yield }\end{array}$ & $\begin{array}{l}\text { ASTM } \\
\text { Limits }\end{array}$ \\
\hline Specific gravity $\left(\mathrm{g} / \mathrm{cm}^{3}\right)$ at & 0.89 & $\mathrm{NS}$ \\
$15^{\circ} \mathrm{C}$ & 0.7 & $0.08 \mathrm{max}$ \\
Acid value $(\mathrm{mgKOH} / \mathrm{g})$ & 27.5 & $\mathrm{NS}$ \\
API gravity & 5.6 & $1.9-6.0$ \\
Kinematic viscosity at $40^{\circ} \mathrm{C}$ & & $\mathrm{NS}$ \\
$(\mathrm{cSt})$ & 3.5 & $\mathrm{~N}$ \\
Cloud point $\left({ }^{\circ} \mathrm{C}\right)$ & $1 \mathrm{~b}$ & $\mathrm{No} .3 \mathrm{max}$ \\
Copper strip corrosion & 0.02 & $0.05 \mathrm{max}$ \\
Water and sediment & 1380 & $1300^{\circ} \mathrm{min}$ \\
Flash point $\left({ }^{\circ} \mathrm{C}\right)$ & -3 & $\mathrm{NS}$ \\
Pour point $\left({ }^{\circ} \mathrm{C}\right)$ & 35.1 & 47 \\
Cetane number & 53 & $48-65$ \\
Aniline point $\left({ }^{\circ} \mathrm{C}\right)$ & &
\end{tabular}

The fuel properties of the biodiesel produced from Lageneria vulgaris seeds oil were obtained using the biodiesel oil with the best yield of $94.8 \%$ when eggshell was used as catalyst. Since the fatty acid content dictates the specific gravity, a denser vegetable oil will give a denser biodiesel (Rick Da Tech, 2017). Biodiesel have a specific gravity range of about 0.86 to 0.90 . The specific gravity of Calabash seed oil biodiesel is 0.890 . This indicates that the product obtained was lower than the value obtained from the oil extracted (0.925). However, it was higher than 0.82 and 0.8879 values obtained by Mukhtar et al., 2015 and Sokoto et al., 2013 respectively. Although, it is lower than the calabash seed oil biodiesel value of 0.90 (Olaofe et al., 2012).

The acid number is an important fuel property; it is a measure of free fatty acid in a given product (Mukhtar et al. 2014). The free fatty acids can lead to corrosion and may be a symptom of water in the fuel. The requirement was an ASTM maximum value of $0.8 \mathrm{mgKOH} / \mathrm{g}$ (Kilonzi et al., 2015).
The estimated acid value of the biodiesel produced was $0.7 \mathrm{gKOH} / \mathrm{g}$ which has a corresponding free fatty acid value of $0.25 \%$. The acid value falls below the maximum ASTM limit of 0.8 , although it was higher than acid value of 0.44 (Sokoto et al., 2013). This result indicates that the biodiesel produced may not cause severe corrosion in the internal combustion engine and fuel system.

The petroleum industry uses API Gravity as an indication of energy content of the fuel. As API Gravity increases, the energy content decreases. Since specific gravity is the inverse of API Gravity, a higher specific gravity means a higher energy content fuel. As specific gravity increases, both power output and mileage increases. The API limits for Diesel are 30 to 45 , which translates to specific gravity of 0.876 to 0.802 . Since it is useful as a field test for diesel, there is a strong desire to apply this to biodiesel (Rick Da Tech, 2017). The calabash seed oil biodiesel has an API gravity of 27.5 which is lower than that of diesel limit of 30 to 45 , which is an indicative of high energy content fuel.

Viscosity is the measure of fluid resistance to flow. Biodiesel viscosity varies between arrange 1.9 - 6.0 ASTM D6751 (Van-Gerpen et al., 2004). It is a basic design specification for the fuel injectors used in diesel engines. If the viscosity is too high, the injectors do not perform properly (Kilonzi et al. (2015). The lower the viscosity of the biodiesel, the easier it is to pump and atomize and achieve finer droplets. The kinetic viscosity of the biodiesel produced was $5.6 \mathrm{~mm}^{2} / \mathrm{s}$ which was higher than $5.4 \mathrm{~mm}^{2} / \mathrm{s}$ obtained by Sokoto et al. (2013). It is within the accepted ASTM limit for any biodiesel product.

Under low temperature conditions, paraffinic constituent of biodiesel fuel may be precipitated as a wax. This settles out and blocks the fuel system lines and filters, causing malfunctioning or stalling of the engine. The cloud point test is a guide to the temperature at which it may clog filter system and restrict flow. The cloud point of 


\section{Umar et al: Microwave Assisted Biodiesel Production From Lagenaria Vulgaris Seed Oil Using......}

calabash seed oil biodiesel was $3.5^{\circ} \mathrm{C}$ which was slightly higher than $3.3^{\circ} \mathrm{C}$ of the same plant biodiesel as reported by Sokoto et al. (2013).

Copper strip corrosion test serves as a measure of possible difficulties with copper and brass or bronze parts of fuel system. The presence of acids or sulphur containing compounds can tarnish the copper strip, thus indicating the possibility for corrosion. The ASTM number 3 max was the maximum acceptable value on the scale of 1 to 4 of the copper strip corrosion analysis. The estimated value of $1 \mathrm{~b}$ was recorded for the calabash seed oil biodiesel, and it was within the approved ASTM limit.

Water and sediment measures the cleanliness of a fuel. In the case of biodiesel, it is particularly important because water can react with esters to make free fatty acids and can support microbial growth in storage tanks. Water can be a problem in biodiesel due to its tendency to contribute to degradation during storage, since it can cause operability problems and damage to engines. Water can cause hydrolysis reactions with the methyl esters in biodiesel and produce free fatty acids, which increases the acidity of the fuel. Water and sediments in biodiesel are limited collectively to $0.05 \%$ volume by centrifuge as specified by ASTM D2709. 0.02 was obtained as the value in water and sediment test which is within the acceptable limit of $0.05 \mathrm{max}$. It is also similar to 0.02 value obtained by Mukhtar et al. (2014).

The flash point of the Calabash seeds oil methyl ester is much lower than conventional oils (nonbiodiesel oil) and higher than diesel. The flash point of biodiesel produced from Calabash seed oil was $138^{\circ} \mathrm{C}$ i.e. higher than conventional diesel $\left(55^{\circ} \mathrm{C}\right)$. Liquid fuel with a higher flash point can prevent auto ignition and fire hazard at higher temperature during transportation and storage periods. Hence, the higher the flash point, for instance, the higher is the safety during handling, transportation and storage.
The pour point of a fuel is an indication of the lowest temperature at which the fuel can be pumped. The pour point does give a useful guide to the lowest temperature to which a fuel can be cooled without setting (Speight, 2002). The pour point obtained was $-3{ }^{\circ} \mathrm{C}$ which was higher than $4{ }^{\circ} \mathrm{C}$ reported for calabash seed oil biodiesel by Awulu et al. (2015).

The Diesel Index indicates the ignition quality of the fuel. It is found to correlate, approximately, to the cetane number of commercial fuels (Sokoto et al., 2013). Lower cetane values result in smoky exhaust, affects cold starting and emission of particulate matter. The Diesel index (Cetane number) of 35.1 was obtained for the analyzed calabash seed biodiesel and it is higher than 23.65 estimated by Sokoto et al. (2013) on the same type of plant oil. Although it is lower than the approved ASTM value of 47 . The lower cetane index obtained on the analyzed ester could be due to low aniline value and API gravity; therefore, cetane improver can be added to enhance its ignition quality (Sokoto et al. 2013).

\section{CONCLUSION}

The study involves production of biodiesel from Lageneria vulgaris (Calabash) seeds oil in the presence of Amberlyst 15 ion exchange resin and calcium oxide from treated waste Eggshell as catalysts. The catalytic performances of the catalysts were studied for biodiesel production at various catalyst concentration, different temperature range and different time frame under constant (fixed) oil amount and methanol oil ratio with microwave oven as heating source. The results showed that biodiesel yield of $94.80 \%$ when treated waste eggshell was used as catalyst, while $93.2 \%$ was obtained when Amberlyst 15 ion exchange resin was used. It can be concluded that the best yield of biodiesel was obtained when eggshell was used as catalyst. Hence, an efficient catalyst could be produced from locally available eggshell for biodiesel production. 


\section{Nigerian Journal of Basic and Applied Science (December, 2018), 26(2): 88-96}

\section{REFERENCE}

ASTM D1298 (1999), standard practice for density, relative density (Specified gravity) or API gravity of crude petroleum and liquid petroleum products. Retrieved at:

law.Resource.Org/pub/us/cfr/ibr/003 https:// astm.d1298.1999.pdf, accessed on $15^{\text {th }}$ October, 2018.

ASTM D611 (1982), Standard Test Method for Analine Point and Mixed Analine Point of Petroleum Products and Hydrocarbon Solvents. CFR Section: 21 CFR 177.1520(b) American Society for Testing and Materials.ASTM International, Standard Library.

Akoh, C.C., Chang .S., Lee. G., Show. J. (2007).Enzymatic approach to biodiesel production. Journal of Agricultural and Food chemistry 55(22):8995-9005.

Antczak, M.S., Kubiak, A., Bielecki. S. (2009).Enzymatic biodiesel synthesiskey factor affecting efficiency of the process.Renewable Energy, 34(5):11851194

Anya.U.A.,Nwabia N.C.O and Foegbu. O. (2012).Optimazed reduction of free fatty acid content on neemseed oil, for biodiesel production.Journal of Basic and Applied Chemistry, 2(4).21-28.

Awulu J. O., Ogbeh G.O. and Asawa N. D. (2015).Comparative analysis of biodiesel from calabash and rubber seeds oils. International journal of renewable energy development (IJRED).4(2): p 131-136 Retrieved:

http://ejournal.undip.ac.id/index.php/ijred/ article/view/8638.

Coker A. K, (2010). Ludwig's applied process design for chemical and petrochemical plants.Volume 2, fourth edition.Gulf professional publishing.Oxford, UK. p287.

Colombo, K., Endera, L., André A., and Barros, C. (2017).The study of biodiesel production using $\mathrm{CaO}$ as a heterogeneous catalytic
reaction.Egyptian Journal of Petroleum, 26(2): 341-349.

Danjuma.M.N., and Dandago.M.A(2009). Extraction and characterization of calabash (lageneriasinceratia) seed oil. Techno. Science Africana Journal, (3), 71-76.

Dorfman I. (2000). Density of cooking oil. The physics factbook: An encyclopedia of scientific essays. Retrieved at:http://hypertextbook.com/facts/2000/in ga Dorfman.shtml.

Fjerback, L.K.,Christension.V.andNordhal.B. (2009). A review of current state of biodiesel production using Gossypifoliaspecies.Biotechnologybioengineering 102:1298-1315.

Galvez, R., and Berge.J. (2013).Utilization of fish waste. Boca Raton: CRC press. p 210.

Kaplan. N, Bayko D. B. (2014). A review of new methods used for the production of biodiesel. Petroleum and Coal 56 (1) 6273.

Kilonzi, F.M., Kumar, A., Namango, S.S., Kiriamiti H.K. and Some.D.K. (2015).Optimization of transesterification of sunflower oil with ethanol using eggshell as heterogeneous catalyst. Chemical and Process Engineering Research, 3022247467.

Margarita. S, Giselo M (2011) Biodiesel- feed stocks and processing technologies published by intech, janezatidine 9,51000 rijeka, croata

Marwaha, A.; Dhir, A.; Mahla, S.K.; Mohapatra, S.K.2018.An overview of solid base heterogeneous catalysts for biodiesel production.Catalysis Reviews. 60, 594628.

Mukhtar, M., Muhammad.C.,Dabai M. U. and Mamuda M. (2014). Ethanolysis of calabash (lageneriacenceratia) seed oil for the production of biodiesel. American journal of energy engineering.volume 2(6) p141-145.Science publishing group (Science PG). 


\section{Umar et al: Microwave Assisted Biodiesel Production From Lagenaria Vulgaris Seed Oil Using......}

Olaofe, O.,Ogungbenle, H.N.,Akhadelore, B.E.,Idris, A.C.,Omojola, O.V., Omotehinse.O.T. and Ogunbodele,O.A. (2012). Physico chemical and fatty acids composition of oils from some legume seeds. International Journal of Biology, Pharmacy and Allied Sciences(IJBPAS), 1(3):355-363.

Rick Da Tech(2017). Specific gravity and biodiesel, Make biodiesel. Retrieved at :www.make-biodiesel.org/biodieselchemistry/specific-gravity-andbiodiesel.html, accessed on $15^{\text {th }}$ October, 2018.

Speight.J.G. (2002).Handbook of petroleum products analysis.John wiley and sons, inc., publication. New Jersey.

Sokoto.M.A., Hassan L.G., Salleh M. A., Dangoggo. S. M. and Ahmed H. G. (2013).Quality assessment and optimization of biodiesel from lageneria vulgaris (calabash) seeds oil. International Journal of Pure and Applied Sciences and Technology, 15(1) p5566.ISSN 2229-6107
Van- Gerpen O. J. Shanks B., Pruszko R., Clements, D. and Knothe G. (2004).Biodiesel analytical methods. National Renewable Energy Laboratory 1617 Cole Boulevard, Golden, Colorado 80401-3393-303-275-3000. Operated for the U.S. Department of Energy Office of Energy Efficiency and Renewable Energy by Midwest Research Institute Contract No. DE-AC36-99-G010337

Vasudevan, P.T. and Briggs, M. (2008).Biodiesel production, current state of the art and challenges.Journal of industrial microbiology and biotechnology,35(5), 421430.

Verma, R.M.,(2001). Analytical chemistry Theory and practice, third edition. CBS Publishers and distributors,New Delhi, India. p492.

Ziku, W., Chunli., Baoxin, L.(2008). Application of waste eggshell as low -cost solid catalyst for biodiesel production. Bioresource Technology, 100(11): 2883-2885 